\title{
A Hermeneutical Study on The Symbolic Meaning of The Number 144,000 in Revelation 7:1-17
}

\author{
Yosua Feliciano Camerlingl)* Robi Panggarra ${ }^{2)}$ \\ Armin Sukri Kanna ${ }^{3)}$ Yunus Daniel Anus Laukapitang ${ }^{4)}$ \\ 1, 2,3,4) Sekolah Tinggi Filsafat Theologia Jaffray Makassar \\ ${ }^{*}$ Correspondent author:yosuacamerling@gmail.com
}

Received: 08 February 2021/ Accepted: 28 March 2021/ Published: 09 April 2021

\begin{abstract}
This study aims to analyze and reveal the symbolic meaning of "the number those who were sealed: 144,000 from all the tribes of Israel" in Revelation 7:1-17 and implications for the mission. The research method used is qualitative research carried out with the principles and hermeneutic methods of the Bible. The Bible's hermeneutic method is divided into two characteristics, namely general hermeneutics and specific ones. For the general hermeneutic interpretation method, the author uses three existing analyses structural analysis, grammatical analysis and theological analysis. Then for the particular hermeneutic interpretation method, the author uses the interpretation of number symbols. The results of this study reveal that the symbolic meaning of "the number those who were sealed: 144,000 from all the tribes of Israel" in Revelation 7:1-17 are symbolic numbers of the number redeemed by the Lamb who made it through the tribulation period by remaining faithful to the end of being followers of Christ. As for the theological implications of the text of Revelation 7:1-17 for the mission, namely God Protects His People (7:1-3), God is Consistent with His Promise of Salvation (7:4-8) and God Grants Universal Salvation (7:9-17). As for the practical implications of the text of Revelation 7:117 for the mission, namely Believers are sealed as servants of God (7:1-8), Believers glorify God (7:9-12) and Believers receive sanctification and God's providence $(7: 13-17)$.
\end{abstract}

Keywords: 144,000, church, mission, revelation 7: 1-17, seal

Abstrak

Penelitian ini bertujuan untuk menganalisis dan mengungkapkan makna simbolik dari "144.000 yang telah dimeteraikan dari semua suku keturunan Israel" dalam Wahyu 7:1-17 dan implikasinya terhadap pelayanan misi. Adapun metode penelitian yang digunakan adalah penelitian kualitatif yang dilaksanakan dengan prinsip-prinsip dan metode hermeneutik Alkitab. Metode hermeneutik Alkitab terbagi atas dua sifat yaitu hermeneutik yang sifatnya umum dan yang sifatnya khusus. Untuk metode penafsiran hermeneutik umum penulis menggunakan tiga analisis yang ada yakni analisis struktur, analisis gramatikal dan analisis teologis. Kemudian untuk metode penafsiran hermeneutik khusus, penulis menggunakan penafsiran simbol angka. Hasil dari 
penelitian ini mengungkapkan bahwa "144.000 yang telah dimeteraikan dari semua suku keturunan Israel," dalam Wahyu 7:1-17 merupakan angka simbolik dari jumlah yang ditebus oleh Anak Domba yang berhasil melewati masa kesusahan dengan tetap setia sampai akhir menjadi pengikut Kristus. Adapun implikasi teologis dari teks Wahyu 7:1-17 terhadap pelayanan misi yakni Allah Menyediakan Perlindungan Bagi Umat-Nya (7:1-3), Allah Konsisten Terhadap Janji Keselamatan-Nya (7:4-8) dan Allah Menganugerahkan Keselamatan yang Bersifat Universal (7:9-17). Adapun implikasi praktis dari teks Wahyu 7:1-17 terhadap pelayanan misi yakni Orang Percaya Dimeteraikan Sebagai Hamba Allah (7:1-8), Orang Percaya Memuliakan Allah (7:9-12) dan Orang Percaya Menerima Pengudusan dan Pemeliharaan Allah (7:13-17).

Kata-kata Kunci: 144.000, Gereja, Meterai, Misi, Wahyu 7:1-17.

\section{Introduction}

There are so many different interpretations of the number 144,000 based on Revelation 7:1-17. Seventh-day Adventist theologian Loron Wade in his research reveals that nothing is more confusing than the various views about the 144,000 people who are sealed from Revelation 7. Also, Lynn Huber also expressed his view that the symbol for the number 144,000 is labeled by modern Bible scholars as "the most confusing" of the existing symbols. In his research, he examined that the 144,000 could also mean a community of virginal men who were staunch followers of the Lamb. That is why he said that studying the 144,000 symbols would contribute to the construction of the early Christian gender ideology. ${ }^{2}$

Coupled with the research conducted by Michael Troxell in his thesis entitled The Order and Significance of the Sealed Tribes of Revelation 7:4-8 which states that the list of "144,000 was sealed from all the tribes of Israel," in Revelation 7: 4-8 has been the subject of debate for years. The order of the list of the tribes of Israel in the text does not match any of the Old Testament lists. Judah is on the first list while Reuben the firstborn is second. John also omits the tribes of Dan and

' Loron Wade, "Thoughts on the 144,000," Journal of the Adventist Theological Society 8, no. 1-2 (1997): 90, http://archive.atsjats.org/07Wade-Thoughts97.pdf.

${ }^{2}$ Lynn R. Huber, "Sexually Explicit? Re-Reading Revelation's 144,000 Virgins as a Response to Roman Discourses," Journal of Men, Masculinities and Spirituality 2, no. 1 (January 2008): 3, https://search.informit.com.au/fullText;dn=321990097335985;res=IELHSS. 
Ephraim but then includes the tribes of Levi and Manasseh, in contrast to Ezekiel's list which still includes Dan and Ephraim (Ezek. 48). ${ }^{3}$

One of the debates that arise in the interpretation of this text is the difference of opinion between Richard Bauckham and Christopher Smith. Smith argues that Revelation 7 speaks not only of the church as the new Israel but also of the church built on the apostles (Rev. 21:14). Just as Mathias replaced Judas Iscariot, so was Dan who was replaced by Manasseh because according to tradition (Irenaeus), the Antichrist would come from the tribe of Dan. This opinion was immediately rejected by Bauckham, who argued that the Anthristic tradition would come from the tribe and it was not found in the Jewish text and the Jewish apocalyptic Antichrist figures were always Gentiles. ${ }^{4}$

In his research, Bauckham argues that the Antichrist is the power of the Roman empire. Then the replacement of Dan by Manasseh is hardly a convincing parallel to the replacement of Judas by Matthias. Manasseh frequently appears in lists of the tribes of Israel, but always along with Ephraim in Joseph's place..$^{5}$ That is why the author wants to examine whether this is a symbol for the church or can this picture be understood in a more literal sense like the Jews or the Jewish Christians?

According to G. K. Beale, as quoted by Andrew Brake in his book, there are five possible differences in interpreting this text. 1) Some commentators understand the number 144,000 as literal and conclude that those who are sealed are a remnant of ethnic Israelites; 2) Some commentators link 7:3-8 to the prophecy in Rom. 11:24-26 that all ethnic Israel will be saved at Christ's second coming; 3) Feuillet sees this group as a Christian remnant of ethnic Jews living in the first century, contrasted with unbelieving Jews of that time. This remnant emerged as a result of the destruction of Jerusalem in 70 A.D.; 4) Many commentators rightly understand the number to be figurative, since

${ }^{3}$ Michael W. Troxell, "The Order and Significance of the Sealed Tribes of Revelation 7:4-8" (Master's Theses, Andrews University 2011), 3,

https://digitalcommons.andrews.edu/cgi/viewcontent.cgi?article=1055\&context=theses

${ }^{4}$ Christopher R. Smith, "Portrayal of the Church as the New Israel in the Names and Order of the Tribes in Revelation 7:5-8," JSNT 39, no. 12 (January 1990): 115, https://journals.sagepub.com/doi/abs/10.1177/0142064X9001203907.

${ }^{5}$ Richard Bauckham, "The List of the Tribes in Revelation 7 Again," JSNT 42, no. 13 (January 1991): 100-101, https://journals.sagepub.com/doi/abs/10.1177/0142064x9101304206 
nearly all other numbers in the book have figurative significance. Here, the group who is sealed represents the complete number of God's people. 144,000 is the result of the square of twelve multiplied by one thousand, or the multiple of the squares of then and twelve multiplied by ten. The use of twelve (and perhaps ten) heightens the figurative idea of completeness. The identity of the group is imbued with the fact that they are Israelites; 5) 144,000 is the figurative number for the totality of being redeemed. Option 5 is the commentary position of this book. ${ }^{6}$

Also, in a study conducted by Joseph Aruan and Gerry Takaria related to the 144,000 groups in Revelation 7 and 14 in the Seventh Day Adventist Church members of the Cimindi Raya Bandung Church, both concluded that the results of the study showed that members of the Cimindi Raya congregation did not yet have an uncertain understanding of who and what the number 144,000 means. To that end, the two researchers suggested that a more in-depth study of this text be conducted to obtain the best results. ${ }^{7}$ Therefore, this is why the author re-examine the text of Revelation 7:1-17 and find its implications for the mission.

\section{Method}

In preparing this research, the author used a variety of qualitative research carried out with the principles and methods of biblical hermeneutics. Hermeneutics is important in biblical interpretation because it is a discipline that considers the concepts, principles and laws that are used universally to understand and interpret the Bible. ${ }^{8}$

${ }^{6}$ Andrew Brake, Visi-visi Anak Domba (Makassar: Sekolah Tinggi Theologia Jaffray, 2018), 170; G. K. Beale, The Book of Revelation(The New International Greek Testament Commentary) (Grand Rapids, Michigan: William B. Eerdmans Publishing Company, 1999), 416-422.

7 Josephin Aruan dan Gerry Takaria, "Analisis Teologis Kelompok yang Dimeteraikan Itu: 144.000 Berdasarkan Kitab Wahyu 7 dan Wahyu 14 Di Jemaat Cimindi Raya Bandung," Jurnal Koinonia 9, no. 2 (December 2017): 20-21, https://jurnal.unai.edu/index.php/koinonia/article/view/2277/1646.21.

${ }^{8}$ Hasan Sutanto, Hermeneutik: Prinsip dan Metode Penafsiran Alkitab (Malang: Literatur SAAT, 2007), 3. 
According to Hasan Sutanto, the Bible's hermeneutic method is divided into two characteristics, namely general hermeneutics and specific ones. ${ }^{9}$

For general hermeneutics, the author will use some general interpretation principles and methods developed by Gordon D. Fee in his book New Testament Exegesis and Darell L. Bock and Buist M. Fanning in his book Interpreting the New Testament Text. The author's analytical methods in this study are structural analysis, grammatical analysis and theological analysis. Furthermore, for specific principles and methods, the author uses the principle of symbolic interpretation developed by Kevin J. Conner and Ken Malmin in their book, Interpreting the Scriptures. In this section, the author focuses only on the principle of interpreting the symbolic number "the 144,000 sealed from all the tribes of Israel" in Revelation 7: 4.

Then in compiling this research, the writer uses data collection techniques through library research by using the Bible as the primary literature and using books and several journals from the internet as secondary literature ${ }^{10}$ to formulate various conclusions regarding the hermeneutic study of the symbolic meaning of "the number those who were sealed: 144,000 from all the tribes of Israel" in Revelation 7: 1-17 and the implications for missionary.

\section{Result and Discussion}

\section{Structural Analysis of Revelation 7:1-17}

According to Robert Wall, one of the apocalyptic uniqueness found in the book of Revelation is apocalyptic compositions have structural unity. The author often repeats similar words and phrases in inverted (A B C C' B' A') or chiastic (A B C D C' B' A') order..$^{11}$ Therefore,

\footnotetext{
${ }^{9}$ Sutanto, Hermeneutik: Prinsip dan Metode Penafsiran Alkitab, 7; Henry A. Virkler, Hermeneutics: Principles and Processes of Biblical Interpretation (Grand Rapids: Baker Book House, 1981), 16.

${ }^{10}$ Yosua Feliciano Camerling, "Analisis Biblika Tentang 'Kota-Kota Perlindungan' Berdasarkan Ulangan 19:1-13 Dan Relevansinya Bagi Gereja Masa Kini,” Pengarah: Jurnal Teologi Kristen 2, no. 2 (July 2020): 143, https://doi.org/10.36270/pengarah.v2i2.27.

${ }^{11}$ Robert Wall, Revelations (New International Bible Commentary) (Grand Rapids: Baker Books, 1991), 14-15.
} 
the author will analyze and describe the text structure of Revelation 7:117 by following the composition of the inverted order.

Based on the author's study of this text, the apostle John divided Revelation 7: 1-17 into two major sections of thought. First, the 144,000 sealed from all the tribes of the descendants of Israel (7:1-8). Second, countless multitudes from all over the earth (7:9-17).

I. 7:1-8 144,000 people who have been sealed from all tribes Israel

A. 7: 1-2 John's vision of the four Angels on Earth

B. 7:3 Angel's call to restrain punishment on earth

C. 7:4-8 Characteristics of the 144,000 sealed

From All Tribes of Israel's Descendants

II. 7:9-17 Countless multitudes from all over earth

C.' 7:9 The characteristics of a countless

multitude from all over the earth

B.' 7:10-12 The cry of a multitude for receiving salvation in Heaven

A.' 7:13-17 John's conversation with one of the elders in Heaven

\section{Grammatical Analysis of Revelation 7: 1-17}

Hayes and Holladay suggest that grammatical analysis focuses not only on how words function as meaning carriers but how they are organized into phrases and sentences to form a meaningful unit. ${ }^{12}$ For this reason, in this section, the author will try to reveal the meaning of grammar in the text of Revelation 7:1-17.

144,000 people who have been sealed from all tribes Israel (7:1-8)

This first point summarizes some of the events in which the 144,000 were sealed from all the tribes of the house of Israel. In his vision, the apostle John testified that great danger would occur on earth if God released him as a punishment for the sins of the world. But in his interpretation, de Heer reveals that chapter 7 informs the reader that there is a protection that comes from God's side to the believer. ${ }^{13}$ The following is a description of this text.

12 John H. Hayes dan Carl R. Holladay, Pedoman Penafsiran Alkitab (Jakarta: Gunung Mulia, 2015), 69.

${ }^{13} \mathrm{~J}$. J. de Heer, Tafsiran Alkitab: Wahyu Kepada Yohanes (Jakarta: Gunung Mulia, 2015), 97. 
John's vision of the four Angels on earth (7:1-2)

Verses 1-2 describe John's vision of seeing four angels holding back the four winds of the earth so that no wind would blow on the land, or the sea, or on trees. According to Brake, the idea of the number "four" symbolizes the whole world. So, when John records these four angels standing at the four corners of the earth, it is referring to the whole world. This view is also in line with that expressed by Osborne that the angels standing "in the four corners of the earth" is an ancient idiom for each part of the world (Ezek. 7:2). ${ }^{14}$

Furthermore, it says in verse 2 that John saw another angel emerge from where the sun rose. According to Kistemaker, other words indicate that this angel is equal to the four angels who hold back the earth's winds. It comes from the east which is the place where the sun rises, which is also the source of light. Therefore, Kistemaker provides a comparison of the Jerusalem Temple facing east to focus on the rising sun and the presence of God (Ezek. 43:2). ${ }^{15}$ This view parallels de Heer who reveals that Ezekiel also saw a vision of God's glory coming from the east (Ezek. 43:2), and in Malachi 4:2 the salvation that comes from God compared to the rising of the sun. ${ }^{16}$

Based on these views, the author conclude that this angel was commissioned by God to carry the seal of the living God. That means again the apostle John wants to show his readers that those who endure will be protected from the wrath of the Lamb. That is why Wiersbe argues that the "seal" expressed in this passage will protect the Israelites who are God's chosen people from judgments that will "destroy the earth and the sea." ${ }^{17}$

Referring to the context of protection given, Hagelberg revealed that several interpretations state that this is spiritual protection. However, according to him this refers more to physical protection because in the context of this passage what threatens is calamity and

${ }^{14}$ Grant R. Osborne, Revelation (Baker Exegetical Commentary on the New Testament) (Grand Rapids, Michigan: Baker Academic, 2008), 305.

${ }^{15}$ Ibid., 305.

16 de Heer, 97.

${ }^{17}$ Warren W. Wiersbe, Pendalaman Perjanjian Baru - Wahyu: Berkemenangan Di Dalam Kristus (Bandung: Kalam Hidup, 2002), 76. 
wind which is physical in nature. ${ }^{18}$ Therefore, the author concludes that the protection given in this text is more of a physical nature because the punishment that will be imposed is also physical rather than spiritual.

Angel's call to restrain punishment on earth (7:3)

Verse 3 explains explicitly the content of another angel's loud cry not to destroy the earth or the sea or the trees before Allah's servants is sealed on their foreheads. According to de Heer's commentary, he compared John's vision with the vision in Ezekiel 9 wherein the text describes a protection mark on the foreheads of God's servants which is marked with the letter T. ${ }^{19}$ This view is also in line with Brake's commentary that this seal uses the Hebrew letter "Tau" which is not a $\mathrm{T}$ in English or Greek, but in the early Jewish tradition the + or x sign is Christianity the sign of the cross is usually used. ${ }^{20}$

For this reason, Hendriksen gave his view that this seal has three functions, namely: (1) Preventing damage; (2) Guarantee ownership; and (3) For a document stating the authenticity. ${ }^{21}$ Furthermore, Kistemaker in his book reveals that the relevance of the seal for the saints themselves is divided into three parts, namely: (1) They are safe and no one, including the devil, can take them from the hand of God (John 10:28); (2) They have God and they are His; (3) His word to them is true and unchanging, His promises remain. ${ }^{22}$ Based on this, the author concludes that the seal marks on God's servants symbolize protection and freedom from punishment. In the end, it is this seal that will make them rejoice in the presence of the Lamb. On the other hand, those who do not have the seal will face the wrath of the Lamb and the wrath of God (Rev. 6:15-17). Characteristics of the 144,000 sealed from all tribes of Israel's descendants (7:4-8)

In this verse, it is recorded that the number of those who were sealed from all the tribes of the house of Israel was 144,000. The characteristics of the division were that of the tribe of Judah twelve

${ }^{18}$ Dave Hagelberg, Tafsiran Kitab Wahyu dari Bahasa Yunani (Yogyakarta: ANDI, 2005), 182.

19 de Heer, 98.

${ }^{20}$ Brake, 168.

${ }^{21}$ William Hendriksen, Lebih dari Pemenang: Sebuah Interpretasi Kitab Wahyu (Surabaya: Momentum, 2008), 128; Beale, 409-415.

22 Simon J. Kistemaker, Tafsiran Kitab Wahyu (Surabaya: Momentum, 2014), 267. 
thousand that were sealed, of the tribe of Reuben twelve thousand, of the tribe of Gad twelve thousand, of the tribe of Asher twelve thousand, of the tribe of Naphtali twelve thousand, of the tribe of Manasseh twelve thousand, of of the tribe of Simeon twelve thousand, of the tribe of Levi twelve thousand, of the tribe of Issachar twelve thousand, of the tribe of Zebulun twelve thousand, of the tribe of Joseph twelve thousand, of the tribe of Benjamin twelve thousand.

Various interpretations try to give their opinion about the composition of the tribes of Israel. However, if one looks closely, the list of descendants of the tribes of Israel is not the same as that found in the Old Testament. The following is a list of comparisons of the tribes of Israel in Revelation, Genesis, and Ezekiel presented in table form. ${ }^{23}$

Table 1. List Comparison of the Tribes of Israel in Revelation 7, Genesis 49 and Ezekiel 48

\begin{tabular}{ccc}
\hline Revelation 7 & Genesis 49 & Ezekiel 48 \\
\hline Judah & Reuben & Dan \\
Reuben & Simeon & Asher \\
Gad & Levi & Naphtali \\
Asher & Judah & Manasseh \\
Naphtali & Zebulun & Ephraim \\
Manasseh & Issachar & Reuben \\
Simeon & Dan & Judah \\
Levi & Gad & Benjamin \\
Issachar & Asher & Simeon \\
Zebulun & Naphtali & Issachar \\
Joseph & Joseph & Zebulun \\
Benjamin & Benjamin & Gad \\
\hline
\end{tabular}

Referring to the above list of comparative tribes of Israel, some interpreters agree that this is symbolism because there is a perfect harmony i.e., the 12 tribes each of 12,000 people indicate a fulfilment. Therefore, it is probable that this grouping shows the same group as verse 8 which is an uncountable number. ${ }^{24}$ Referring to this, de Heer quotes the view of W. Hadorn who argues that the 144,000 people who are sealed are a picture of the entire Christian church, but are still built

${ }^{23}$ George Eldon Ladd, A Commentary on the Revelation of John (Grand Rapids:

William B. Eerdmans Publishing Company, 1993), 115.

${ }^{24}$ Brake, 169. 
from two concentric circles (circles that have one centre). The inner circle is of Israelites who have believed in Christ but around them is a larger circle, namely, of unbelievers who have believed in Christ and as "new branches grafted on the tree of Israel," (Rom. 11: 17-24). ${ }^{25}$

Therefore, the author concludes this section by citing Ladd's view that the meaning of the number 144,000 comes from $12 \times 12 \times 1000$ which affirms that the full number of God's people will be carried safely through the tribulation; not one of God's people will be lost. ${ }^{26}$ Referring to this, readers no longer need to question the order of the tribes of Israel in Revelation 7 because according to Mounce, the tribes are listed in some eighteen different orders in the Old Testament. ${ }^{27}$

However, it should also be noted the views of several interpreters regarding the order of the syllables in this text. According to Mounce, the Dan tribe was not included because they originally worshipped idols (Judg. 18:30) and because they built places of worship that were not according to the word of God (1 Kings 12:29) ${ }^{28}$ While Brake gives his view that the tribe of Judah is in the first place, which is an unusual placement because he is the fourth child. Judah may come first because David was from the tribe of Judah and in Ezekiel 34:23 God promised to make David their shepherd. Judah may be in the first place because Jesus himself is described as the lion of Judah who also comes from the sprout of David (Rev. 5:5). ${ }^{29}$

Furthermore, Joseph and Manasseh's names are listed because Joseph received a double inheritance from Jacob/Israel because his two sons, namely Ephraim and Manasseh respectively, inherited the land in Canaan. Ephraim is not listed because Ephraim is the representative name for the nation of Israel, the northern kingdom that turned away from God; it is also associated with idolatry in Hosea 4:17-14:8. ${ }^{30}$ Here are some interpretations that explain the order of the tribes of Israel in the text of Revelation 7:5-8. Based on the entire explanation in this section,

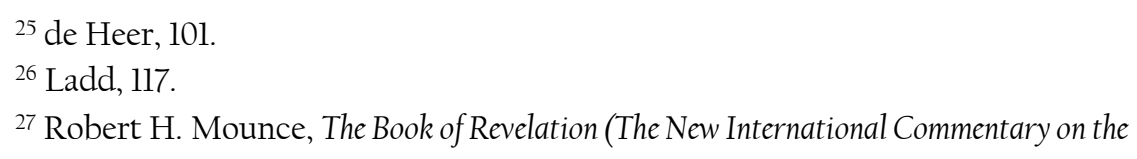

${ }^{27}$ Robert H. Mounce, The Book of Revelation (The New International Commentary on the New Testament) (Grand Rapids, Michigan: William B. Eerdmans Publishing Company, 1979), 170.

\footnotetext{
28 Ibid., 169.

29 Brake, 169.

${ }^{30}$ Brake, 169-170.
} 
the author concludes that the 144,000 who were sealed from all the tribes of the house of Israel are the symbolic number of the number redeemed by the Lamb who survived the tribulation by remaining faithful to the end of being followers of Christ. They are described as the perfect totality of God's church on this earth.

For this reason, in this section, the author will present the principle of interpreting the number symbol described by Conner and Malmin to reveal the symbolic meaning of the "144,000 who have been sealed from all the tribes of the descendants of Israel" in Revelation 7:4. ${ }^{31}$

\begin{tabular}{|c|c|c|}
\hline Symbolic Numbers & Shared Characteristics & Symbolized \\
\hline 12 (Gen. 49:28) & God's Chosen People & The tribe of Israel \\
\hline 12 (Matt. 10:2) & Followers of Christ & Disciples of Jesus \\
\hline 144,000 (Rev. 7:4) & $\begin{array}{c}\text { The amount that is } \\
\text { sealed }\end{array}$ & The tribe of Israel \\
\hline 144,000 (Rev. 14:1, 3) & Amount redeemed & Followers of the Lamb \\
\hline
\end{tabular}

Figure 1. Display of the 144,000 Numeral Symbol

Referring to the above display of the symbol of the number 144,000 , it can be concluded that the "144,000 who have been sealed from all the tribes of the house of Israel" in Revelation 7: 1-17 describe the complete totality of the followers of the Lamb. These are God's people from both the Old and New Testaments who have faithfully followed God to the end of their lives. For that, at the end of time, they will receive protection in the form of a seal from the Lamb of God and His Father so that they do not get the wrath of the Lamb and the wrath of God. Even though there is a possibility that they will get the wrath of the dragon, they are still able to endure suffering and persecution to the end.

\section{Countless multitudes from all over earth (7:9-17)}

This second point of thought summarizes some of the events that tell of countless multitudes from all over the earth. The Apostle John begins this section by saying "Then from that..." According to Hagelberg,

\footnotetext{
${ }^{31}$ Kevin J. Conner and Ken Malmin, Interpreting The Scriptures (Malang: Gandum
} Mas, 2004), 253. 
this phrase indicates that this vision was different from the one inspired in chapters $7: 1-8 .{ }^{32}$ In this passage, it is illustrated that a great multitude who came from all nations and tribes and peoples and tongues stood before the throne and before the Lamb to raise their praise for the victory they had won.

The characteristics of a countless multitude from all over the earth (7:9)

There are various interpretations of the multitude that the apostle John witnessed in this section. According to Wiersbe, the multitude pictured here came from "all nations and tribes and peoples and languages" (7:9). ${ }^{33}$ It is interesting to notice the use of the phrase "all nations" in this passage. The phrase "all nations" comes from the Greek ethnos which is a rather odd grammatical list because it initially denotes the singular but is later followed by three plurals: "tribe, people and language." Osborne quoted Bauckham's view that the singular "all nations" echoes the promise to the ancestors in Gen. 7:4 (You will become the father of many nations) while the plural "tribe" carries "all the tribes of Israel" in verses 4-8, states that Jewish (Gentile) Christians together make up all of God's people. ${ }^{34}$

This view is parallel to Brake quoting Beale who gives his view that this multitude reminds readers of God's promises to Abraham in Genesis 13:16 and Genesis 17:4-6 where John refers to the Cyruses as spiritual Israel or the new Israel. ${ }^{35}$ Therefore, according to the author, this multitude does not intend to replace Israel's people. However, their existence to fulfil that there are repentant Israelites plus other nations who receive salvation (Rom. 11).

It is further illustrated that this crowd was wearing white robes and holding palm leaves in their hands. The white color in the book of Revelation represents the glory of heaven and the sanctity of life. The meaning of the palm fronds held by them has two kinds of meanings. JJ de Heer in his interpretation mentions that palm leaves in the ancient world were a sign of victory (cf. Apocryphal Book of 1 Maccabees 13:5l) but at the same time, palm leaves remind us of the Feast of Tabernacles which means that it is a feast day. The tabernacle of the Israelites

\footnotetext{
${ }^{32}$ Hagelberg, 186.

${ }^{33}$ Wiersbe, 78.

34 Osborne, 319.

${ }^{35}$ Brake, 171-172; Beale, 427.
} 
remembers the difficult journey through the wilderness (Lev. 23:42-43) likewise in this chapter the church also celebrates a feast of deliverance in heaven after going on a difficult journey in the world. ${ }^{36}$ That is why Brake thinks this victory is earned through sacrifice, much like Jesus' victory on the cross. ${ }^{37}$ Referring to this section, the writer concludes that this is a symbol of real victory where the victory is obtained through a process full of suffering.

The cry of a multitude for receiving salvation in Heaven (7:10-12)

In verses 10-12 it is depicted that this multitude is crying out with a loud voice: "Salvation is to our God who sits on the throne and to the Lamb!" According to de Heer, the exclamation comes from Greek: he soteria toi theoi hemon, which is translated by the Revised Standard Version literally as Salvation belongs to our God so that it can be translated in Indonesian as "Salvation for God" which means that salvation comes from God. ${ }^{38}$ Based on this, the writer also agrees that the salvation these people get, of course, comes only from God alone. That is why they raise their praise with loud voices as an expression of their gratitude to God, the Source of Salvation.

Therefore, Brake gives his view that this represents a lofty Christological statement about Jesus because just as God has the authority to provide salvation, so does the Lamb. ${ }^{39}$ Also, Kistemaker believed that their victory praise was similar to the "Hosanna" (Lord, help us!) Praise that the people sang when the Lord Jesus entered Jerusalem (Matt. 21:9). ${ }^{40}$ Based on this, the author conclude that the basis of their commendation is because they realize that their salvation is guaranteed not because of who they are but solely because of the great role of the blood of Jesus. It is only through the blood of Jesus that they can receive salvation. For that, this praise was reciprocated by the angels, elders, and the four creatures ${ }^{41}$ with "Amen" which was a term

${ }^{36}$ Also, in Zech. 14:16 Indeed, a close relationship has been established between the Feast of Tabernacles and eschatology, and in fact, the Book of Zechariah is used a lot in Revelation. de Heer, 104; Beale, 425.

${ }^{37}$ Brake, 172.

38 de Heer, 104.

39 Brake, 173.

${ }^{40}$ Kistemaker, 273.

${ }^{41}$ The description of these four creatures can be found in Ezekiel 1:5-28. 
often used in Jewish circles to approve their praise. ${ }^{42}$ This approval is followed by the words "praise and glory, and wisdom and thanksgiving, and honor and power and strength to our God forever and ever! Amen!" Groen reveals that these seven words of praise to Allah are like a chain that can be connected over and over again as infinite and unending praise. ${ }^{43}$ Referring to this, the writer concludes that this illustrates that the praise between a group of people and the angel of God agrees on the praise that is proper and proper to be given to Allah which can be done continuously because He is indeed worthy to receive it.

John's conversation with one of the elders in Heaven (7:13-17)

In this section, it is described that one of the elders in heaven having questions with the apostle John. At first, he asked that "Who are those who wear white robes and where did they come from?" It is interesting to see Groen's equivalence that this is like a teacher who gives a question to students about one of the subjects. ${ }^{44}$ This view is parallel to Kistemaker's statement that the question-and-answer technique is the oldest teaching method. It is generally not students who ask questions but teachers who ask sharp questions that demand indepth answers. ${ }^{45}$

Based on this, Mounce reveals that this question-and-answer pattern is commonly used in the prophets (Zech. 4:5; Jer. 1:11. 13; 24: 3; Am. 7:8; and 8:2). ${ }^{46}$ Referring to this, the author concludes that this is one of the similarities between the book of Revelation and the prophets in the Old Testament. The answer given by John is "My lord, you know it." The word "my lord" in this passage comes from the Greek кúpı $\varsigma^{47}$ (kurios) which is used to denote God or lord, which of course shows John's respect which he also expressed in Rev. 19:10 and 22:8-9.48 Referring to this, Kistemaker gave his view that John could have been surprised at the question given by one of the elders because how could

\footnotetext{
42 de Heer, 105.

${ }^{43}$ J. P. D. Groen, Aku Datang Segera: Tafsiran Kitab Wahyu (Surabaya: Momentum, 2002), 117.

${ }^{44}$ Ibid., 117.

${ }^{45}$ Kistemkaer, 275.

${ }^{46}$ Mounce, 173.

${ }^{47}$ Revelation 7:14 BGT Version, BibleWorks Greek LXX/BNT in BibleWorks 8.

${ }^{48}$ Mounce, 173.
} 
he not know who the crowd was. ${ }^{49}$ That was why he then replied with great respect that one of the elders would know the answer and could answer his question.

Furthermore, the answer from one of the elders was related to the existence of these people who were sealed, namely, they were people who came out of great distress, and they have washed their robes and made them white in the blood of the Lamb. According to Groen, the term "great tribulation" used in this passage is also used by Daniel who prophesied that there would be a time of great tribulation for the Jews (Dan. 12:1). ${ }^{50}$ Whereas more clearly, Kistemaker gave his view that the

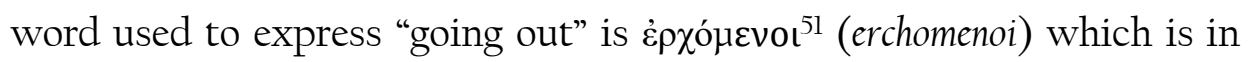
the form of the present participle ("is coming out") but the word is often translated as "out" or "has come out." The reason most theologians use the term "has come out" is because the next two words, "have washed the robes" and "have made them white," are in the past tense. ${ }^{52}$ To that end, this phrase shows that this multitude has come out of the suffering and persecution experienced in the world.

In verse 15 , it is described that they stand before the throne of God and serve Him day and night in His temple. According to Brake, the word to serve in this section comes from the Greek $\lambda \alpha \tau \rho \varepsilon v$ ovouv (latreuousin) which symbolizes the priesthood. Those who worship the Lamb will joyfully and willingly give Him glory for that is where the greatest joys and gratifications of humanity lie. ${ }^{53}$ This view is also in line with Kistemaker's opinion that the record of heavenly joy is repeated in the last chapter that "The throne of God and the throne of the Lamb will be in it and His servants will worship Him," (22:3). ${ }^{54}$ Through this, the reader can know that the relationship between God and humans is reestablished, and they are even said to be joyful in serving Him day and night in His temple.

Then it was said, and he who sits on the throne will spread His tabernacle over them. According to Kistemaker, this phrase is a poetic

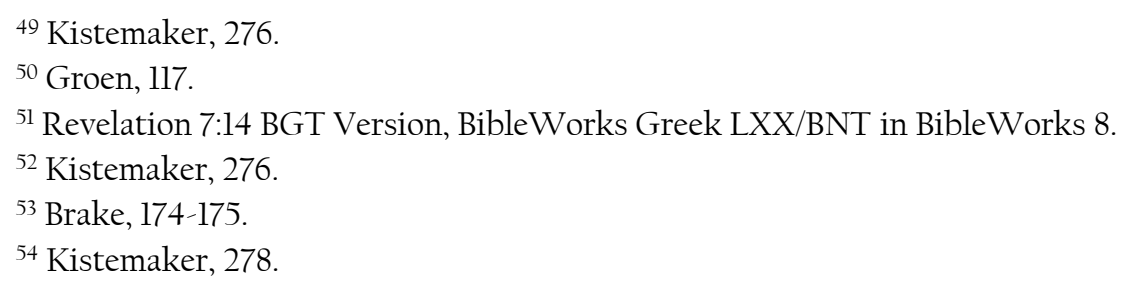


description of God's protection for His people. ${ }^{55}$ Referring to this view, the author concludes that a reciprocal relationship occurs when humans gather together with God in heaven. They will serve God and God will provide them with protection so that through this, they can experience His presence.

For this reason, in verse 16, they will no longer suffer from hunger and thirst, and the sun or scorching heat will not befall them again. According to de Heer, "hunger and thirst, sun or scorching heat" are physical suffering symbols and are often spiritual (Isa. 55:1). ${ }^{56}$ Based on this view, the author concludes that this text describes physical suffering and is broader than that they will also be liberated from spiritual suffering. Again, in this text, John wants to show his readers that even though they are in physical and spiritual suffering, they will eventually escape it all while in the protection and presence of God in heaven.

This is further strengthened by the statement of the apostle John in verse 17. Referring to this verse, it is interesting to see Groen's view that usually sheep would be escorted by his shepherd to get their food. But in this text, the apostle John testified that the Lamb himself is the Shepherd who shepherds His flock. ${ }^{57}$ Therefore, Hagelberg expressed his view that indeed the Lamb who is told in the book of Revelation is truly extraordinary. ${ }^{58}$ For this Lamb will lead His people to the wells of water of life.

At the end of this verse, there is a promise of participation that Allah will give to His people. The promise is that God will wipe away every tear from them. According to Kistemaker, this passage describes the perfect state of life because there will be no more death, no more mourning, or weeping, or sorrow, for all that is old has passed away (Rev. 21:4) .59 $^{59}$ This view is parallel to what Groen expressed that God would comfort and comfort them so that they would never again remember their old suffering (Rev. 21:4). ${ }^{60}$ To that end, the author concludes that God will promise true protection and comfort to His people who are going through great tribulation.

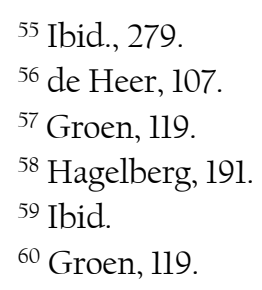




\section{Theological Analysis of Revelation 7:1-17}

This analysis aims to find, search for and formulate any theology contained in the biblical text. ${ }^{61}$ Referring to the whole discussion of the text of Revelation 7: 1-17, in this section the author will present the practical theological implications of the symbolic meaning of "the number those who were sealed: 144,000 from all the tribes of Israel" in Revelation 7:1-17.

\section{Theological Implications}

God Protects His People (7:1-3)

Although in this text it is not explicitly written that God protects His people, in verses 1-3 the apostle John illustrates that the punishment is held by the four angels until the servants of God are sealed on their foreheads. This view was supported by Morris, who stated that God's wrath was withheld until God's servants were sealed. ${ }^{62}$ Referring to this, the author argues that one of the descriptions of God's character in this passage shows that He always protects those who will follow Him diligently. Of course, this is one proof that He is truly sovereign over all the lives of His people.

Even though sometimes people don't realize this, God's protection is truly extraordinary. This passage describes a God who is truly sovereign (He is almighty and omniscient), and He is transcendent (in Himself $\mathrm{He}$ exists beyond space and time). His supervision and protection cover creatures whose feelings are sensitive to even inanimate objects. ${ }^{63}$ Therefore, let every believer be able to recognize and give a glorious response to one of the attributes of God discussed in this passage, where He is Sovereign God and not only that but He is a God who truly watches over and protects His people.

As for the relation to the missionary ministry of the church, the teaching about God's protection needs to be taught to every believer so

${ }^{61}$ Sonny Eli Zaluchu, Biblical Theology Pembahasan Metodologi dan Pendekatan Biblika Dalam Membangun Teologi PL dan PB (Semarang: Golden Gate Publishing, 2017), 38-39.

${ }^{62}$ Canon Leon Morris, The Book of Revelation: An Introduction and Commentary (The Tyndale New Testament Commentaries) (Leicester, England: Inter-Varsity Press, Grand Rapids, Michigan: William B. Eerdmans Publishing Company, 1999), 116.

${ }^{63}$ D. A. Carson, Doktrin yang Sulit mengenai Kasih Allah (Surabaya: Momentum, 2010), 52-53. 
that they will persevere in waiting for God even though they are in the midst of challenges and suffering on this earth. If they remain faithful in His followers, there is protection that Allah provides for each of His followers. Therefore, presumably through this section, the church may respond to God's call by remaining faithful servants of God because only those who endure to the end will be sealed (protected) by God.

God is Consistent with His promises of salvation (7:4-8)

Furthermore, the theological implication of the text of Revelation 7: 1-17 for the church's mission is that God is consistent with His promise of salvation. It is found in verses 4-8 where the apostle John lists the descendants of Israel who were sealed by God. Indeed, if we refer to Genesis 12, it can be seen that God chose and blessed Abraham to become a great nation. After that, all the people on this earth will receive a blessing through their descendants.

From Abraham, Isaac was born and Isaac was born Jacob, who is known as Israel. Through Israel that 12 tribes were born, which were believed to be a blessing for all the peoples of the earth so that other nations would know and know who God is. Nevertheless, along the way, Israel failed to be an example to other nations. Israel failed to become God's chosen people who would bring other nations to know God. On the contrary, they are more exclusive in their traditions.

This view was also expressed by Hery Sutanto, who in his research revealed that if it was drawn to the Old Testament era, God chose the Israelites so that other nations would know and know who God is and want to live under God's leadership, but the Israelites failed to be good witnesses. because their actions made many nations feel antipathy and leave God. ${ }^{64}$ However, even so, God remains consistent with His promise of salvation. Why not, in verses 4-8 it is stated that 144,000 consists of 12 tribes of Israel, in which there are 12,000, each of which is sealed. It is well known that the seal is a symbol of God's protection. Therefore, in this section, we want to show the reader that God is consistent with His promise of salvation.

${ }^{64}$ Hery Sutanto, "Gereja yang Berfokus pada Gerakan Misioner," Jurnal Fidei 2, no. 1 (June 2019): 69, https://doi.org/10.34081/fidei.v2il.23. 
God Grants Universal Salvation (7:9-17)

When referring to the meaning of salvation itself, C. Groenen gave his view that salvation is the goal of salvation, so it must be understood that saving is a process and that means that the rescue effort does not occur once in human life. ${ }^{65}$ Based on this, the author concludes that God's salvation to every human being is not cheap at all. He gave Jesus Christ, His only begotten Son, to redeem mankind with expensive blood (1 Pet. 1:19) so that everyone who believes in Him may not perish but may have eternal life (John 3:16).

It should be noted that the context of Allah bestowing universal salvation in this passage also states that the salvation obtained by humans is a gift from God. It is not like a father giving his child a gift because he has won a class or a birthday. However, the concept of Allah bestows salvation more than that. In her research, Dessy Handayani revealed that her actions do not determine human salvation, but based on the grace from God received through faith in the Lord Jesus Christ as Lord and Savior. Salvation is not due to human work or deeds, but salvation is only a gift of God alone.

However, it should be realized that the term universal about salvation must be understood from the perspective of the believer. That universal does not mean everyone will be saved, but universal means that salvation is bestowed on believers from various ethnic backgrounds (nationality), people, and languages. That is why God longs to see that all people on earth can believe in Jesus so that they can receive the salvation that comes from Him. This was proven before His ascension to heaven, He gave a commission for His disciples in Matthew 28: 18-20 to make disciples of all nations. In fact, not only that, but He also stated that: "But you will receive power when the Holy Spirit comes on you, and you will be my witnesses in Jerusalem, and all Judea and Samaria, and to the ends of the earth" (Acts 1:8). Based on this, the author concludes that God's saving action and the Lamb have a universal dimension that refers to every believer on earth.

65 C. Groenen, Soteriologi Alkitabiah: Keselamatan yang Diberitakan Alkitab (Yogyakarta: Kanisius, 1989), 132-133. 


\section{Practical Implications}

Believers are Sealed as Servants of God (7:1-8)

If you look at verses 1-8 it illustrates a loud cry from an angel not to destroy the earth or sea or trees before Allah's servants are sealed on their foreheads. Emphasis especially in verse 3, there is the word ".... sealed as servants of God ..." According to Kistemaker, servants of God not only talk about prophets, pastors, and church officials but all believers, namely those who faithfully serve God, love Him with all your heart, soul, and mind, and love others as yourself. ${ }^{66}$ Based on this, the writer concludes that every believer should be aware of his position before Allah that they have been sealed as servants of Allah. To do this, they need to serve God faithfully and love God and their fellow humans.

The use of the term servant of God has many meanings. A servant of God can be defined as those who are devoted to God. For that, they are called servants of God. Furthermore, the servant of God can also mean that a believer who has been redeemed or purchased by God is called a servant of God. Also, servants of God can mean people who respond to and obey God's call to become evangelists to be called servants of God. However, it should be realized that the phrase "servant of God" has practical consequences in the lives of believers which refers to the establishment of a clear relationship with God through their obedience to God. ${ }^{67}$

This is parallel to the true meaning of the word $\dot{\varepsilon} \sigma \varphi \rho \alpha \gamma i \sigma \mu \varepsilon \dot{v} \omega \nu$ (read: esphragismenon) which is translated: "sealed" which implies that these people become people who have sealed not automatically but as a result of previous actions (faithful and obedient to God and the Lamb) ${ }^{68}$ Referring to this, the writer concludes that God's people must be loyal and obedient to God and the Lamb as their response in obtaining salvation. Therefore, John MacArthur said that a servant of God has the most glorious task of God, the Head of the Church is to fight for the

${ }^{66}$ Kistemaker, 266.

${ }^{67}$ Herlise Yetty Sagala, “Aku Ini adalah Hamba Tuhan,” Sekolah Tinggi Teologi Bandung, http://www.sttb.ac.id/informasi/artikel/44l-aku-ini-adalah-hamba-tuhan. ${ }^{68}$ Meyke Imuly dan Monike Hukubun, "Keselamatan Universal dalam Wahyu 7:1-17," Arumbae 1, no. 1 (2019): 93, http://ojs.ukim.ac.id/index.php/arumbae/article/view/186/133. 
struggle of faith. ${ }^{69}$ It means that despite experiencing suffering and persecution in life, as a servant of God, the church must persist in fighting for its faith because, in the last days, those who endure to the end will be sealed as servants of God and free from punishment.

Believers Glorify God (7:9-12)

In verses 9-12 John describes his vision that an uncountable multitude, from all tribes and peoples and tongues, is standing before the throne and before the Lamb glorifying God using divine praises. Not only that, but the apostle John also witnessed that all the angels, elders, and the four creatures in heaven participated in giving praise to God in return to glorify God. Of course, this is the response of their hearts to the salvation that Allah has given them.

Therefore, Stephen Tong revealed that God created humans not so that humans could live and do as they please. God created man so that man would know he had to glorify God the Creator. ${ }^{70}$ This is what we were created for, our purpose for being redeemed, which is to glorify God. Referring to this viewpoint, the author quotes the words of Jesus in the Gospel of Matthew that: "In the same way, let your light shine before others, that they may see your good deeds and glorify your Father in Heaven," (Matt. 5:16).

Based on these words of Jesus, one form of what a believer can do that can be a blessing to others is to do soul outreach. Mental outreach is an obligation that must be carried out in the mission ministry of the Lord's church. That is why Peter Wongso said that the church as the mandate of God who has received the Great Commission has the responsibility to preach the gospel to every unsaved person..$^{71}$ The contents of the Gospel must focus on the gospel of the Kingdom of God which centres on the whole life of Jesus Christ and not other gospels (cf. Luke 4:43; 24:27; Acts 8:12; 1 Corinthians 2:1-2; Galatians 1:6-10, 11-12, 16). In other words, the preaching of the gospel should place more emphasis on the power of God's word.

${ }^{69}$ Paul. E. Billheimer (trans.), Kemuliaan di Balik Penderitaan (Surabaya: Yakin, 1977), 28.

70 Stephen Tong, "Mengapa Kita Memuliakan Allah?” Artikel Sabda, https://artikel.sabda.org/mengapa_kita_memuliakan_allah.

${ }^{71}$ Peter Wongso, Tugas Gereja dan Misi Masa Kini (Malang: Seminari Alkitab Asia Tenggara, 1996), 129. 
Let every believer dare to speak like Paul and Barnabas to the Jews of Anthiocia in Pisidia regarding God's commandment that: "I have made you a light for the Gentiles, that you may bring salvation to the ends of the earth" (Acts 13:47; Isa. 49:6).

\section{Believers Receive Sanctification and God's Providence (7:13-17)}

Referring to verses 13-17, the text describes John's conversation with one of the elders in heaven. What is at the core of their conversation is related to the final existence of innumerable multitudes from all over the earth. Based on these verses, it can be seen that believers receive God's sanctification and care. God wants to show that humans cannot receive sanctification and care by their produce or labour. However, the sanctification and care that humans get only through their belief that it is only by the blood of Jesus that they receive the sanctification and care of God. That is why the elders say that they have washed their robes and made them white in the blood of the Lamb.

Also, this text speaks of a reciprocal relationship that occurs when humans gather together with God in heaven. They will serve Allah and Allah will provide them with protection and care. For this reason, in verse 16 , they will no longer suffer from hunger and thirst, and the sun or scorching heat will not befall them again. From this text, it is shown that God's providence is physical and refers to a broader thing, namely spiritual matters where they will receive God's care so that they will avoid judgment and condemnation.

Therefore, as believers who have the Most Holy God, we should respond to the holiness that God has given us. God shares His holiness by giving it and giving it through the blood of the Lamb, so He demands that His people also have that holiness. First to the Israelites and then to His church, He said, "Be holy, because I am holy," (1 Pet. 1:16)..$^{72}$ From this explanation, it can be learned that God's holiness should comfort and guarantee every believer to always live-in holiness.

Apart from sanctification, believers will also receive God's care. J. Wesley Brill revealed that God's providence is related to the power of God which applies to the lives of His creatures. ${ }^{73}$ Through God's power, all creatures will be preserved until God's purpose is fulfilled in the life

\footnotetext{
72 A. W. Tozer, Mengenal yang Mahakudus (Bandung: Kalam Hidup, 2006), 150.

${ }^{73}$ J. Wesley Brill, Dasaryang Teguh (Bandung: Kalam Hidup, 2015), 101.
} 
of His creatures. Of course, this also speaks of God's care for the mission. God not only sends His people but also maintains the implementation of the Great Commission.

This is evidenced by the Great Commission which Christ gave to His disciples. The contents of the Great Commission are "Then Jesus came to them and said, 'All authority in heaven and on earth has been given to me. Therefore, go and make disciples of all nations, baptizing them in the name of the Father and the Son and of the Holy Spirit, and teach them to obey everything I have commanded you. And surely, I am with you always, to the very end of the age," (Matt. 28: 18-20). This Great Commission ends with the extraordinary promise that Jesus not only sends disciples to make disciples of all nations but also helps sustain them to the end of time. He will not leave them but will give them His Holy Spirit so that the disciples can boldly convey the message of the Gospel to the entire nation. Therefore, the author conclude that believers receive God's providence in doing the mission.

\section{Conclusion}

The author concludes that the symbolic meaning of "the number those who were sealed 144,000 from all the tribes of Israel" in Revelation 7:1-17 is from $12 \times 12 \times 1000$ which affirms that the full number of God's people will be carried safely through the tribulation; not one of God's people will be lost. Referring to this, the readers will no longer need to question the order of the tribes of Israel in Revelation 7 because the names of the tribes of Israel are recorded in 18 different orders in the Old Testament. This shows that the reader need not focus too much on the order of the tribes of Israel in this text because in the Old Testament itself there is no fixed order for the list of tribes of Israelite descent.

As for the theological implications of the hermeneutic study of the text of Revelation 7: 1-17 on mission service, it produces several truths, namely God protects His people (7:1-3), God is consistent with His promises of salvation (7:4-8) and God grants universal salvation (7:9-17). As for the practical implications of the hermeneutic study of the text of Revelation 7: 1-17 on mission service, it produces several truths, namely: Believers are sealed as servants of God (7:1-8), Believers glorify God (7:912) and believers receive sanctification and God's providence (7:13-17). 


\section{Bibliography}

Aruan, Josephin and Gerry Takaria. "Analisis Teologis Kelompok yang Dimeteraikan Itu: 144.000 Berdasarkan Kitab Wahyu 7 dan Wahyu 14 Di Jemaat Cimindi Raya Bandung." Jurnal Koinonia 9, no. 2 (December 2017): 1-24.

https:/jurnal.unai.edu/index.php/koinonia/article/view/2277/1646. 21.

Aune, David E. Revelation 6-16, vol. 52B, Word Biblical Commentary. Dallas: Word, Incorporated, 1998.

Bauckham, Richard. "The List of the Tribes in Revelation 7 Again." JSNT 42, no. 13 (January 1991): 99-115.

https://journals.sagepub.com/doi/abs/10.1177/0142064x9101304206.

Beale, G. K. The Book of Revelation (The New International Greek Testament Commentary). Grand Rapids, Michigan: William B. Eerdmans Publishing Company, 1999.

Billheimer, Paul. E. (trans.). Kemuliaan di Balik Penderitaan. Surabaya: Yakin, 1977.

Bock, Darrell L. and Buist M. Fanning. Interpreting the New Testament Text: Introduction to the Art and Science of Exegesis. Wheaton, Illinois: Crossway Books, 2006.

Brake, Andrew. Visi-visi Anak Domba. Makassar: Sekolah Tinggi Theologia Jaffray, 2018.

Brill, J. Wesley. Dasaryang Teguh. Bandung: Kalam Hidup, 2015.

Camerling, Yosua Feliciano. "Analisis Biblika Tentang 'Kota-Kota Perlindungan’ Berdasarkan Ulangan 19:1-13 Dan Relevansinya Bagi Gereja Masa Kini." Pengarah: Jurnal Teologi Kristen 2, no. 2 (July 2020): 141-155. https://doi.org/10.36270/pengarah.v2i2.27.

Carson, D. A. Doktrin yang Sulit mengenai Kasih Allah. Surabaya: Momentum, 2010.

Conner, Kevin J. and Ken Malmin. Interpreting the Scriptures. Malang: Gandum Mas, 2004.

Davids, Peter H. Ucapan yang Sulit dalam Perjanjian Baru. Malang: Literatur SAAT, 2000.

de Heer, J. J. Tafsiran Alkitab: Wahyu Kepada Yohanes. Jakarta: Gunung Mulia, 2015.

Fee, Gordon D. New Testament Exegesis Eksegesis Perjanjian Baru. Malang: Literatur SAAT, 2011.

Groen, J. P. D. Aku Datang Segera: Tafsiran Kitab Wahyu. Surabaya: Momentum, 2002. 
Groenen, C. Soteriologi Alkitabiah: Keselamatan yang Diberitakan Alkitab. Yogyakarta: Kanisius, 1989.

Hagelberg, Dave. Tafsiran Kitab Wahyu dari Bahasa Yunani. Yogyakarta: ANDI, 2005.

Handayani, Dessy. "Tinjauan Teologis Tentang Iman dan Perbuatan Bagi

Keselamatan.” Jurnal Epigraphe 1, no. 2 (November 2017): 91-103.

http://dx.doi.org/10.33991/epigraphe.vli2.16.

Hayes, John H. and Carl R. Holladay. Pedoman Penafsiran Alkitab. Jakarta: Gunung Mulia, 2015.

Hendriksen, William. Lebih dari Pemenang: Sebuah Interpretasi Kitab Wahyu. Surabaya: Momentum, 2008.

Huber, Lynn R. “Sexually Explicit? Re-Reading Revelation's 144,000

Virgins as a Response to Roman Discourses." Journal of Men,

Masculinities and Spirituality 2, no. 1 (January 2008): 3-28.

https://doi.org/10.31826/9781463226114-008

Imuly, Meyke and Monike Hukubun. "Keselamatan Universal dalam

Wahyu 7:1-17." Arumbae 1, no. 1 (2019): 86-107.

https://doi.org/10.37429/arumbae.vlil.186

Kistemaker, Simon J. Tafsiran Kitab Wahyu. Surabaya: Momentum, 2014.

Ladd, George Eldon. A Commentary on the Revelation of John. Grand Rapids: William B. Eerdmans Publishing Company, 1993.

Morris, Canon Leon. The Book of Revelation: An Introduction and Commentary (The Tyndale New Testament Commentaries). Leicester, England: InterVarsity Press, Grand Rapids, Michigan: William B. Eerdmans Publishing Company, 1999.

Mounce, Robert H. The Book of Revelation (The New International Commentary on the New Testament). Grand Rapids, Michigan: William B. Eerdmans Publishing Company, 1979.

Osborne, Grant R. Revelation (Baker Exegetical Commentary on the New Testament). Grand Rapids, Michigan: Baker Academic, 2008.

Sagala, Herlise Yetty. "Aku Ini adalah Hamba Tuhan." Sekolah Tinggi

Teologi Bandung. http://www.sttb.ac.id/informasi/artikel/44l-akuini-adalah-hamba-tuhan. https://doi.org/10.31219/osf.io/p6jn3

Smith, Christopher R. "Portrayal of the Church as the New Israel in the Names and Order of the Tribes in Revelation 7:5-8." JSNT 39, no. 12 (January 1990): 11l-118. https://journals.sagepub.com/doi/ abs/10.1177/0142064X9001203907.

Sutanto, Hasan. Hermeneutik: Prinsip dan Metode Penafsiran Alkitab. Malang: Literatur SAAT, 2007. 
Sutanto, Hery. "Gereja yang Berfokus pada Gerakan Misioner.” Jurnal Fidei 2 no. 1 (June 2019): 62-80.

https://doi.org/10.34081/fidei.v2il.23.

Thomas, Yohanes Christopher and Frank D. Macchia. Revelation(The Two Horizons New Testament Commentary). Grand Rapids, Michigan: Eerdmans, 2016.

Tong, Stephen. "Mengapa Kita Memuliakan Allah?" Artikel Sabda. https://artikel.sabda.org/mengapa_kita_memuliakan_allah.

Tozer, A. W. Mengenal yang Mahakudus. Bandung: Kalam Hidup, 2006.

Troxell, Michael W. "The Order and Significance of the Sealed Tribes of Revelation 7:4-8." Master's Theses, Andrews University, 2011. https://digitalcommons.andrews.edu/cgi/viewcontent.cgi?article=1 $055 \&$ context=theses.

Virkler, Henry A. Hermeneutics: Principles and Processes of Biblical Interpretation. Grand Rapids: Baker Book House, 1981.

Wade, Loron. "Thoughts on the 144,000." Journal of the Adventist Theological Society 8, no. 1-2 (1997): 90-99. http://archive.atsjats.org/07WadeThoughts97.pdf.

Wall, Robert. Revelations (New International Bible Commentary). Grand Rapids: Baker Books, 1991.

Wiersbe, Warren W. Pendalaman Perjanjian Baru - Wahyu: Berkemenangan Di Dalam Kristus. Bandung: Kalam Hidup, 2002.

Wongso, Peter. Tugas Gereja dan Misi Masa Kini. Malang: Seminari Alkitab Asia Tenggara, 1996.

Zaluchu, Sonny Eli. Biblical Theology Pembahasan Metodologi dan Pendekatan Biblika Dalam Membangun Teologi PL dan PB. Semarang: Golden Gate Publishing, 2017. 